\title{
The Commonwealth Local Government Forum: An Overview
}

\author{
Commonwealth Journal of Local Governance \\ Issue 1: May 2008 \\ http://epress.lib.uts.edu.au/ojs/index.php/cjlg
}

\author{
Lucy Slack \\ Commonwealth Local Government Forum
}

\section{Introduction}

The Commonwealth Local Government Forum (CLGF) was established in 1994, coinciding with rapid moves towards decentralisation at that time, especially in Commonwealth Africa. It uniquely brings together national associations of local government and individual councils, ministries responsible for local government, and training and research institutes with an interest in local government, on a common platform. This reflects an understanding that local government needs effective central government and vice versa if decentralisation is to be truly successful, and that research, training and practice need to be brought together in a constructive and creative way.

CLGF's developmental work can be divided into three main categories:

- Promotion and advocacy of local democracy and good governance

- Exchange of experience

- Capacity building

This article provides a brief overview of the activities and projects which CLGF has underway in respect of these objectives. It will be complemented by more detailed papers on specific programmes and projects in this and future issues of the Commonwealth Journal of Local Governance.

\section{Promotion and advocacy of local democracy and good governance}

CLGF actively promotes and advocates for democratic, elected local government around the Commonwealth. The organisation's commitment to democratic values is set out in the Aberdeen Agenda: Commonwealth principles on good practice for local democracy and good governance, which was developed and adopted at its 2005 Conference in Aberdeen, and 
subsequently endorsed by Commonwealth Heads of Government in the same year. CLGF aims to ensure that local government's role as a sphere of government is recognised and reflected nationally and internationally. It also works directly with its members to strengthen local governance structures and to develop more democratic local government.

For example CLGF regularly collaborates with the Commonwealth Secretariat to monitor local elections, at the request of the countries concerned. This support usually focuses on countries which are establishing elected local government for the first time or re-establishing it after a long gap eg Sierra Leone in 2004 and Lesotho in 2005. Typically, a small expert team observes the whole electoral process and then produces a report which focuses on identifying capacity building needs to ensure ongoing improvement in the electoral system.

CLGF has also piloted a process for turning the principles in the Aberdeen Agenda into a practical tool for its members to use to assess the health of local democracy in their countries. Developed together with its partners in Uganda (Ministry of Local Government, Uganda Local Governments Association, Ugandan Management Institute and Makerere University), the approach involves a research study into each of the principles undertaken by a local research organisation/university, followed by a national verification workshop bringing together all of the key stakeholders councillors, local government officials, ministry representatives, MPs, NGOs, community leaders etc to discuss the report and to make recommendations for strengthening local democratic processes.

In Uganda discussion highlighted the enabling legislation which makes provision for all of the principles. Detailed discussions focused around the local accountability of centrally appointed district administrators and the reduction in locally raised revenue. Another key element of the review was to identify good practices through specific case studies. The final report reflecting workshop discussions and containing a series of recommendations for change and development was presented to President Museveni and widely published. This approach has been endorsed by Commonwealth Heads of Government and further studies are planned.

\section{Exchange of Experience}

The Commonwealth offers a vast array of experience, expertise and good practice in decentralisation and local government. CLGF seeks to draw out case studies of good practice and identify expertise and knowledge which can be shared to support learning and strengthen systems and practice more effectively. Alongside the Commonwealth Journal of Local Governance, CLGF publishes an annual Commonwealth Local Government Handbook. This sets out within a comparative framework a summary of local government systems and structures in all Commonwealth countries. The entries are also available on the CLGF website at www.clgf.org.uk 
CLGF convenes a biennial Commonwealth Local Government Conference and also convenes regional and country-specific seminars and symposiums on policy issues such as gender, local government service partnerships, strengthening national associations of local government and localising the Millennium Development Goals (MDGs).

A recent workshop in Nigeria, organised with the national association of local government, ALGON focused specifically on sharing Commonwealth experience to assist ALGON to improve their lobbying strategy and also to address the relationship between local government and state government. Similarly a workshop in Kuala Lumpur, 2005 brought together practitioners from across Asia to address ways in which partnerships, including with the private sector, can help local governments to innovate and deliver better services to their communities.

CLGF's Research Advisory Group provides another vehicle for exchange of information and experience through meetings and preparation of research papers. Recent papers include Delivering Development through Local Leadership by Mike Geddes and Helen Sullivan (the background paper for the 2007 Auckland Conference); and Obtaining a Municipal Credit Rating by Barry Jackson, prepared in partnership with the Development Bank of Southern Africa (see

http://www.clgf.org.uk/index.cfm/pageid/78/Publications).

\section{Capacity building}

CLGF manages a number of major capacity building partnerships across the Commonwealth. Initiatives are designed to strengthen local democratic structures, improve governance and facilitate better service delivery, within the overall context of contributing towards the achievement of global poverty reduction targets including the MDGs.

The Commonwealth Local Government Good Practice Scheme supports capacity building partnerships between local authorities in the UK, Africa and India; and Australia and Papua New Guinea. It is now being extended to New Zealand and Pacific Island states. To date around 30 projects have been funded. For example eThekwini (Durban) Metro in South Africa and Leeds City Council in the UK have worked together on improving procurement in eThekwini and identifying strategies to open up local authority procurement to small, black and ethnic minority businesses. Rajkot in India has partnered with Leicester in the UK to strengthen community consultation as a way of improving water supply in two wards in the city.

Current target countries are South Africa, India, Jamaica, Ghana, Pakistan, Sierra Leone and Papua New Guinea. With the extension to the Pacific, it is expected that over the next five years the Scheme will support more than 
45 individual partnerships. CLGF is also working with a range of stakeholders to launch a regional capacity building project in the Caribbean, similar to its programme in the Pacific (see below). This would also include expansion of the Good Practice Scheme in the Caribbean.

CLGF recently completed a successful Democracy Enhancement Programme in Zimbabwe, which focused on identifying weaknesses in governance and service delivery and facilitated the development of change plans to address them. It brings local practitioners and stakeholders together to agree on their indicators for local democracy, and uses two tools - a system of international peer review developed by CLGF and the Urban Councils Association of Zimbabwe (UCAZ) as part of the project, and the UN-Habitat Urban Governance Index. The latter involves a group of local stakeholders reviewing the quality of governance against certain agreed criteria such as access to information and services. These reviews are combined to provide a basis for change plans.

The Zimbabwe project has been operating in challenging circumstances, however the feedback on its impact has been significant. Not only have the councils involved and their local communities benefited directly, but also UCAZ has been able to secure further funding to roll it out to other councils in Zimbabwe. CLGF for its part, following a successful regional dissemination workshop, is committed to rolling the model out to other member countries, including Zambia and Mauritius. A toolkit setting out the methodology which the project has used will be published shortly and will be available on the CLGF website.

Working with a team of training institutes in South Asia, CLGF is developing training modules based on the Aberdeen Agenda principles. The training modules are being designed for councillors and mayors in the region and will use case practical studies and participatory training tools as part of the methodology. The training tools will be available via the CLGF website and it is hoped that the partner training institutes involved in the project will mainstream them into their regular training.

CLGF's other main capacity building projects are in the Pacific: the Pacific Regional Project and the Honiara City Council capacity building project. These are described in detail in the accompanying paper in this issue by Terry Parker and Megan Praeger. 